\title{
Scientific findings of Alexander von Humboldt's expedition into the Spanish-American Tropics (1799-1804) from a geographical point of view
}

\author{
GERD KOHLHEPP \\ Department of Economic and Social Geography, Center of Latin American Studies \\ Institute of Geography, University of Tübingen, Hölderlinstrasse 12, D-72074 Tübingen, Germany \\ Manuscript received on April 16, 2004; accepted for publication on June 18, 2004; \\ presented by ALCIDES N. SIAL
}

\begin{abstract}
Alexander von Humboldt's expedition from 1799 till 1804 to the "equinoctial regions of the new world" led through Venezuela, Cuba, Colombia, Ecuador, Peru, and Mexico. In Europe an increased knowledge of the "New World" was connected with the privately funded journey, which served purely scientific purposes and had nothing to do with the exploration and exploitation of natural resources. Besides the research results, which were based on new measuring methods and the quantitative ascertainment of scientific basics, the journey also made possible detailed descriptions in matters of regional studies including social, socio-economic, political, and economic-geographic circumstances, which were based on empirical field studies. The expedition took place shortly before the political change in Latin America. Humboldt, who still experienced the feudal character of global economy based on slave labor in the colonies, vehemently criticized this economic structure - although he was a noble - and its unbearable social conditions. This is the reason why Humboldt is still admired in Latin America till this day. In Europe the scientific insights of his journey to the tropics and his innovative impulses in geog raphy as well as in many other disciplines brought him fame and lasting recognition as a universal scholar, who had crucial influence on the development of the sciences during the first half of the $19^{\text {th }}$ century.
\end{abstract}

Key words: historical geography, regional studies, Latin America, Spanish colonies, Alexander von Humboldt.

\section{INTRODUCTION}

With his return to Europe on August 1, 1804 Alexander von Humboldt concluded his famous journey to the "equinoctial regions of the New World." Accompanied by his French friend Aimé Bonpland, a physician, botanist, and zoologist he visited places which are now regions of Venezuela, Cuba, Colombia, Ecuador, Peru, and Mexico from the years 1799 to 1804 .

E-mail: gerd.kohlhepp@uni-tuebingen.de
Not only did this journey mark the transition from the earlier voyages of discovery to a new phase of expeditions focused on clearly and scientifically defined problems, it also conveyed a new view of the "New World" to the European public. In the center of Humboldt's venture was not the state-funded conquest and exploration of natural resources for the exploitation of a colony by its mother country. Humboldt's journey was privately funded and organized, and - without any secondary motives - it served both scientific basic research and 
also the detailed description of the countries in terms of regional studies involving geological, physicalgeographic, historical, socio-economic, socio- and economic-geographical as well as political, sociological, and anthropological facts.

The explorers broke new ground in science with the help of their analytical proceedings on the basis of countless measurements and methods of quantifying observations and their use of modern instruments and the synthetic synopsis in the form of topographic maps, which were more accurate than anything known so far, as well as detailed landscape profiles of the places they visited. The comprehensive collection of thousands of species of plants did not only serve the discovery of new species itself, but, through the barometric ascertainment of altitude and differences in temperature, it also served the creation of a three-dimensional view of the differentiation of natural and cultural areas in tropical high mountain ranges.

Unlike the mere natural scientists of the $18^{\text {th }}$ century Humboldt attached great importance to the careful observation of anthropogenic factors as well as to empirical field studies. In his scientific and methodological concept he was strongly influenced by Immanuel Kant. In his work "Kritik der reinen Vernunft" in 1784 Kant assigned to the empirical sciences the "world of phenomena", which was called "Kosmos" by Humboldt (Beck 1959/1961). Detailed and unprejudiced interviews of all social classes, an evaluation of all available documents, and the collection, systematic classification and interpretation of important statistical data - also in comparison with other regions - made for a higher level of quality in scientific reporting.

\section{DESTINATION: "EQUINOCTIAL REGIONS" OF THE NEW WORLD}

Without ever going into detail about it, Alexander von Humboldt had secretly chosen the tropics as a destination for his journeys since his younger years. Accounts of expeditions and - thanks to the noble standing of the Prussian family - his handpicked tutors gave the first impetus. As had been arranged, he enrolled at the University of Frankfurt on the Oder and studied the unloved fiscal accounting. Before 1810 the Prussian capital Berlin did not yet have a university. He interrupted his university education to pursue intense study in the field of botany as a student of the well-known Willdenow. In 1789 on a field trip during his studies, which he subsequently resumed in Göttingen and at the Hamburg business academy, he became acquainted with Georg Forster, who strengthened his interest in the tropics. At his father's side Forster had taken part in James Cook's second circumnavigation of the globe (1772/1775). The journeys with Forster to Holland, England, and France in 1790 did not only train Humboldt's capacity of observation, but the trip to Paris also had a profound impact, as he was introduced to new ideas of liberty brought about by the French Revolution. In the same year the 21-year old submitted the first draft of his plant geography to Georg Forster.

Humboldt gained intense geological-mineralogical knowledge - including some experience in the economic evaluation of deposits - in his quickly proceeding career as a mining expert in the Prussian civil service and also valuable experience from his studies at the mining academy in Freiberg, Saxony (1791/1792) - a school where a couple of future important geologists from the Spanish-American and Brazilian colonial territories had also studied.

As Beck has clearly shown in his comprehensive studies on Alexander von Humboldt (Beck 1987/1997: cf. Humboldt 1987, 1989a, b, 1991, 1992, 1993, 1997), in 1793 Humboldt already began to systematically prepare the journey to the tropics of the New World. Although journeys were a part of the classical educational program of the elite in Europe, the journey to Italy and Switzerland in 1795 by all means already possessed the character of a research trip. There he did not only transform already existing geological, physicalgeographic, plant-geographic, and astronomic knowledge through observation and also through his contact with scientists from Geneva, but he also tested the most modern instruments and gained practical experience in the determination of loca- 
tion and altitude as well as in the drawing of ground profiles and maps. He also concerned himself with such geographic field studies in Spain while he was waiting for his departure for the New World.

When, after their mother's death, the brothers Alexander and Wilhelm von Humboldt could dispose of a substantial fortune, Alexander's expedition plans were pursued with determination, and the journey to the tropics was most carefully prepared. Despite the best offers he quit his job in the civil service and devoted himself entirely to science. "The West Indies," according to Humboldt's understanding one unit with the tropical Andes regions of northern South and Central America became the designated destination: the "equinoctial regions of the new continent'" (Humboldt 1814/1825), the regions of the tropical equinox.

In 1798 Humboldt initially concentrated his journey preparations on Paris, reckoned as the scientific center of the world. In Paris Humboldt, who had already established a network of scientific contacts all over Central Europe by means of visits and extensive correspondence, met with the very best of the French natural sciences. While his plans to travel to Upper Egypt and to accompany Baudin on a circumnavigation of the globe came to nothing, he became acquainted with Bonpland in Paris. It was he who became Humboldt's companion on his journeys to the New World. Above all he attended to the botanic collections and the description of species.

Thanks to the diplomatic support of the Saxon envoy Forell the Prussian Calvinist Humboldt managed to be received in audience by his majesty, the Catholic King of Spain Charles IV. His scientific reputation and his Spanish language skills - proof of the early purposeful preparation for "The West Indies" and the adjoining regions of the Spanish colonial empire (Beck 1987/1997) allowed the court to place confidence in Humboldt. Although foreigners were not allowed to enter Spanish colonies, he and Bonpland received passports and comprehensive travel permits. This also included the support of local authorities as well as the use of Spanish vessels. Humboldt was aware of the fact that the Span- ish government had never before trusted a foreigner more than him. In comparison the expedition of the French Academy of Sciences in Ecuador and Peru led by La Condamine a few decades earlier suffered from military monitoring and travel restrictions.

Alexander von Humboldt knew that a continuation of his journey from the Rio Orinoco into the Brazilian Amazon-river-system, which was claimed by Portugal, would be impossible. Portugal had guarded its colony Brazil against the Spanish territories. As the Portuguese feared Humboldt might be a spy, the authorities in Rio de Janeiro, at the behest of the King of Portugal, posted a reward for the arrest of Humboldt in case he entered Brazil. A few years later, when Portugal's ruling prince escaped from the French occupation of Portugal under Napoleon to Rio de Janeiro in 1808 , an entirely different situation with opportunities for research would have arisen for Humboldt in Brazil as well. The expeditions of Maximilian, prince of Wied-Neuwied $(1815 / 1817)$ as well as the expeditions, organized by von Spix and von Martius (1817/1820) and many others in different regions of Brazil only a short time later, underlined this development.

\section{THE GEO-POLITICAL SITUATION IN EUROPE AND THE NEW WORLD AT THE TIME OF ALEXANDER VON HUMBOLDT'S JOURNEY}

Toward the end of the $18^{\text {th }}$ century the age of enlightenment had brought about emancipation from political, religious, and social bonds, which dated back to the Middle Ages, in Europe. The French Revolution did not only radiate its ideals onto the political situation but also onto the spiritual life in Europe. The new ideal of liberty was contrasted with the heyday of the European colonial period, which in the New World, was already approaching its end. The political power struggles in Europe became evident when Humboldt left La Coruña. On June 5, 1799 the Spanish frigate narrowly escaped a blockade set up by the English fleet. Europe was on the brink of the rise of Napoleon and the fall of Prussia.

In the New World the United States of Amer- 
ica had already gained its autonomy in 1776. In Haiti the first great slave revolt of the 1790s successfully paved the way to independence in 1804 . In the Ibero-American world, where the Spanish colonial territories had shown themselves to be vulnerable with the temporary English occupation of Cuba, Trinidad, and Florida - in Southeast Asia also the Philippines - the spirit of liberty awoke. Trade barriers between mother country and colonies fell. Navigation, which had been limited to connections between Sevilla, Cádiz and La Habana or Veracruz, was opened to direct traffic with all larger SpanishAmerican ports on the Atlantic side of South America (Buisson 1980). However, the military securing of overseas territories and the reform of the administrative organization remained a priority. After two viceroyalties had existed with New-Spain (Mexico) and Peru until the beginning of the $18^{\text {th }}$ century, two new viceroyalties were created in South America: New-Granada (1793) with Bogotá as its capital comprising today's states of Venezuela, Columbia, and Ecuador and also the viceroyalty of Rio de la Plata (Argentina, Bolivia, Uruguay, Paraguay).

Humboldt's expedition took place shortly before the political change in Latin America, which ended the colonial period - except for Cuba - during the first two decades of the $19^{\text {th }}$ century. Humboldt still came to see the colonial global economy based on slave labor. However, he vehemently criticized this structure as a person who had internalized the ideas of the French Revolution. This is certainly also a reason why Humboldt's name enjoys special veneration in many parts of Ibero-America still today.

In 1804 Alexander von Humboldt had become acquainted with the 21-year old Simón Bolívar. He was son to a rich Creole family from Caracas, who enthusiastically discussed the necessary liberation of the Spanish colonies in South America, also expected by Humboldt. In a letter to Bolívar from July 29, 1822 Humboldt mentioned the "era when we took vows for the liberty and independence of the New Continent"' (Beck 1959). Some time later Humboldt, who admired the great successes of the
"Libertador" of Spanish-America during the first few decades of the $19^{\text {th }}$ century, admitted that he, when he met Bolívar in Paris, did not think him mature enough for the role of a leader of an independence movement. Bonpland, however, assessed his abilities much better (Beck 1959/1961).

\section{THE CHALLENGE OF EXPLORING THE TROPICS AND THE KEY RESULTS OF HUMBOLDT'S EXPEDITION}

The carefully prepared voyage to the West Indies, which he carried out in spite of numerous political problems and obstacles in Europe, was "nevertheless an ingenious improvisation in its realization", (Wilhelmy 1970). While the scientific objectives were accomplished without any significant obstacles the regional itinerary had to be adapted to the respective circumstances again and again. In doing so Humboldt exhibited a great deal of flexibility, pragmatic action, and diplomatic skills. While the voyage was originally meant to take the scientists to Cuba and Mexico, fever onboard the vessel bound for La Habana forced their first stop in the Venezuelan Cumaná in July 1799. As for Humboldt the "laboratory of nature" was available everywhere, the stop turned out to be a 16-month stay in Venezuela, at its core an expedition into the interior lasting several months. Humboldt explored the Llanos and the tropical rainforests of the Rio Orinoco, he traveled on the long unclear connection to the river system of the Amazon, the bifurcation of the Rio Casiquiare, which leads to the Amazontributary Rio Negro (see Fig. 1).

In the center of the stay in Venezuela were the trips in a North-South-profile and the scientific gathering of facts concerning natural environment as well as the economic-geographic situation and the geography of settlements. After the first trips into the coastal mountain ranges and a visit to the missions of the Chaimas-Indians, whose way of life and customs - and those of other Indian tribal groups he studied in great detail, he attended to the capital Caracas, its location, its climate as well as its political relevance. In the Llanos Humboldt posed 


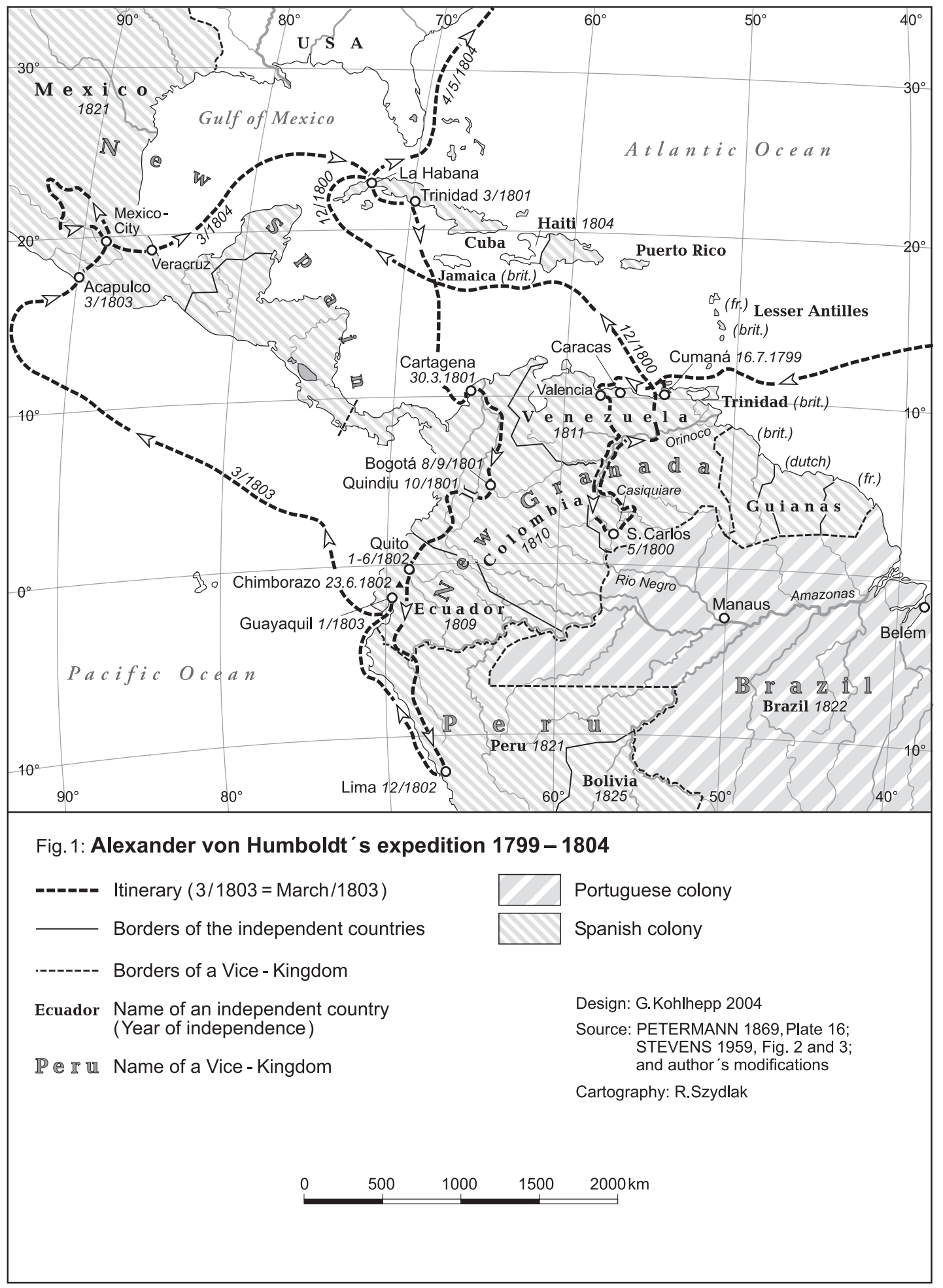

Fig. 1 
the central question of the genesis of the characteristic landscape determining its vegetation and a possible agrarian use in the future (Otremba 1959). Social issues are dealt with through the detailed rendition of numerous informations. He succeeded in the presentation of a zonal division into three sectors from the already settled and agriculturally used coastal regions including parts of the coastal mountain ranges to the wet savannahs of the Llanos with its pasture farming to the tropical rainforests south of the Orinoco, home to Indian hunter-gatherers. The evergreen innertropical forests were named "Hylaea" ("the wooded zone") in 1808 by Humboldt, who used the terminology of Herodotus. He detected the biodiversity of tropical forests compared with forests of the moderate zone, although he was deceived - just as many researchers later on - by the existing biomass of the supposed fertility of tropical forest soils.

In the rainforests Humboldt came across missions as border institutions at the outer periphery, huge areas under the rule of religious orders, which were critically questioned. Isolated forts, military outposts, are meant to secure the borderline between the spheres of influence of the two colonial powers. The contrast between Spanish and Portuguese rule becomes quite evident. There was almost "national hatred" in the borderland, even the "Spanish" and "Portuguese" Indians were blinded by hatred for each other. In a so to speak empirical way the consequences of the chemism of the black and white water rivers is noticed as the unbearable mosquito plague suddenly ceased to torment the explorers at the black water rivers which are poor in suspended particles. The acidity of the water there prevents the growth of mosquito larvae. The accounts are again and again enriched with very well informed comparisons. After his memorial expedition, Vareschi (1959) strongly emphasized the performance of Humboldt and Bonpland. They exposed themselves to the strains of the river expedition without modern equipment, but achieved important scientific results.

The subsequent stay in Cuba was notably short- ened, as there was a chance to take part in the longplanned circumnavigation of the globe starting in Callao in Peru with captain Baudin. Humboldt used the journey from Cuba to go ashore in Cartagena toward the end of March 1801 and explore the Andes in today's states of Colombia, Ecuador, and Peru for the following 20 months. When Baudin's itinerary had changed, Humboldt traveled to Mexico, which he reached in Acapulco (see Fig. 1). As Baudin's itinerary was changed once again, and Humboldt had to give up his South Seas plans and a voyage west to the Philippines and thus the idea of a journey round the world, Humboldt continued exploring in the Mexican highlands. His return journey to $\mathrm{Eu}-$ rope, where he wanted to concern himself with the composition and publication of his results as soon as possible, brought a "detour" by way of the United States of America, where he met with President Jefferson in 1804.

In this paper it is not possible to give a comprehensive summary of the results of Alexander von Humboldt's five-year expedition to the tropics - from which he returned at the age of almost 35 . He himself considered the account of his journey his major achievement and favorite work. This account of his journey goes far beyond the actual travel log "Relation historique" (Humboldt 1814/1825) (see bibliography) and also comprises the "Geographie der Pflanzen" (Humboldt 1805/1807, 1807, 1808a) with the nature painting, the profile table (tableau physique) of the Andes, the work on NewSpain (Humboldt 1811a) and the respective associated atlases (Humboldt 1811b, 1814a, b). Many basic observations are also recorded in essays in the "Ansichten der Natur"' (Humboldt 1808b) and later also in the "Kosmos" (1845/1862). The results of this expedition can also be found in many journals as well as in expert's reports compiled for officials in Mexico. Above all his essay "Essai politique sur le royaume de la Nouvelle-Espagne", (1811) emerged from these reports. The account of his American journey, whose third volume (1825, published in 1831) contains the "Essai politique sur l'̂̂le de Cuba"' (see also Beck 1992), does not com- 
prise the research in Colombia, Ecuador, and Peru. The results can only be found in essays, landscape profiles, and itineraries (Faak 1986) or respectively as hints and comparative observations in his other works. Unfortunately the fourth volume of the journey to the tropics was never published. Due to numerous duties as chamberlain at the court after his return to Berlin in 1827, Humboldt was very busy with the preparation of his Russian-Asian journey and his start of lecturing (Humboldt 1814/1825, 1997).

One example for the unlimited industriousness of the explorers is the fact that they collected 5,800 species of plants. Until then 3,600 of them were still unknown. Most of them were - especially by Bonpland - identified and described during the journey. Within the scope of the plant-geographic and volcanological studies both explorers believed to have reached the hitherto greatest altitude worldwide at the Chimborazo (6,267 $\mathrm{m}$ above sea level) with its $5,880 \mathrm{~m}$ (in reality, due to an error in measurement, only about 5,400 m: Wilhelmy 1986) in June 1802. Recent archaeological findings in the Andes have shown that this was not the case.

Countless measurements to determine locations, for the exact barometric determination of air pressure und thus also the altitude above sea level, temperature, humidity, geomagnetism, air electricity, etc. were made, and many other geophysical, and meteorological measured values were determined. Yet this revolutionary quantification and its interpretation as well as the numerous topographic specifications, as many non-geographers have mistakenly pointed to as his chief accomplishment in the field of geography, was not his central contribution to the discipline. In fact the central issue was the realization of the "interplay of forces" (1808: Ansichten der Natur) in space necessitating many individual evaluations and precise analyses of these forces. Humboldt was not only a natural scientist and the creator of physical geography (then: physic geography, resp. "physique du monde"), but he may also take credit for the almost modern ecological approach of having explored the man-nature- relationship. Not in the sense of a natural determinism but in the sense of correlations and the concurrence in a synthetic view. "He was a genius in productive synthesis" (Plewe 1970).

While scientific geography was still in the process of formation, a decisive step had been made toward substantiated regional studies. It ascribed much importance to anthropogenic circumstances and - influenced by the French physiocrats - land use. To Humboldt the presentation of the human living and economic conditions was so important, that he refused a second invitation of the Russian Czar to Russia and Siberia, because he was asked to report only on the natural conditions and definitely not about people (Plewe 1970). Humboldt replaced the traditional, descriptive, statistically numerating facts about states and products with a thematic and regional issue based approach. He managed to shape a landscape synthesis from different isolated phenomena, and at the same time, scientifically sober objectiveness comes along with an aesthetic aspect. Humboldt focused his attention on the comparative study of landscape types as well as the comparison of regional geographical characteristics.

Critics of Humboldt rightly pointed out, that he continuously mixed up esthetic and scientific points of view, as well textually as in the formal description (Plewe 1970). In the present research on Humboldt, this lack of clarity led to discussions about the "correct" interpretation of Humboldt's remarks. According to the terminology of Romanticism he used terms like "Nature painting of the tropics", "Nature painting of the Chaimas Indians" or "Paintings of special statistics", tending in a stylistic tradition of "painting imagery" of landscape painting of the $18^{\text {th }}$ century (Hard 1970). Hard (1969) emphasized that in the works of Humboldt "Landscape is not a subject of research but an esthetic stimulus and a topic of literary description" (p. 153). Other authors (Stevens 1959, Wilhelmy 1970, among others) however pointed out that Humboldt's esthetic concept of landscape is far less an expression of his subjective view, but a means of perfection of his landscape synthesis. Indisputably he combined sci- 
entific matter-of-factness with his emotional eventful view (Otremba 1959).

The determinations of altitude and the astronomic determination of location as well as trigonometric measurements formed the basis for Humboldt's mapping of reality, but they were also the means for a spatial comparison of certain natural and human phenomena. His work on the altitudinal zonation of vegetation in the Andes - using the innertropical Ecuador as example - was groundbreaking. With his "tableau physique" he created a three-dimensional representation of climatic and vegetation zones, habitat boundaries of the animal world and the economic use in the shape of landscape profiles. In his work on Mexico (1811) he for the first time used the terms - still valid today tierra caliente, tierra templada, and tierra fría for the vertical differentiation of climatic and vegetation zones as well as for types of cultural landscapes. In their research Troll $(1959 b, 1969)$ and later also Lauer (1975) have further analyzed this zoning and the daytime climate of tropical mountain ranges, and they have, with the help of thermoisopleth diagrams, worked out the contrast between the climate of tropical high mountains ("cold" tropics) and the moderate and cold climates of higher latitudes, as already had been stated by Humboldt.

The two "Essais politiques" on New-Spain (Mexico and today's Southwest of the USA) and Cuba were especially important. In these two Humboldt established in the best sense modern, problem-oriented regional studies (Schmieder 1964), the basics of modern geography (StevensMiddleton 1956), which for the first time also systematically set forth economic- and socio-geographic subject-matters. Thanks to the author's exact observations in Mexico they were strongly practice-oriented, e.g. for mining investments and transportation development. They served the government of the viceroyalty New-Spain as the basis for economic-political decisions, particularly as Humboldt had exhausted all available sources in order to edit the most important data. The quality of the available statistics appealed to him, and he believed he could not find anything better in Europe either.

During his stay in Mexico, which lasted almost one year, Humboldt visited the most populous and agriculturally most productive parts of the central region of New-Spain, which had a total population of 5.8 million. His work on Mexico is - besides the physical-geographic basics - a very detailed and differentiated geographic study in terms of population, economy, and society. The descriptions of the population, their racial differentiation and social classification as well as the little importance of slavery - in Mexico-City, unlike in La Habana, Caracas, and Lima, he did not see any slaves in private households - belong to his best accounts. Humboldt saw the source of the viceroyalty's wealth not only in the mines but also in agriculture. He drew a strict distinction between the manifold production of food in Mexico and the inhumane plantation economy based on slave labor in Cuba and Jamaica. Their exports depended heavily upon European pricing. He highlighted the better situation, in comparison to farmers in many parts of Europe, of the poor but also free Indian farmers, although the majority of the Indians lived in utter misery due to the encomienda-system.

In his "Exposé on the main sources of wealth" Humboldt examined - from the perspective of an expert but always with a clear scientific problem in mind - the relationship of economy and state, i.e. also between mother country and colonies. He substantiated his descriptions of regional differences of the social and economic circumstances by means of a detailed presentation of the natural conditions without lapsing into natural determinism - as well as the genesis of the current situation. Humboldt discerned the importance of administrative organization for the spatial planning, and he questioned the principles of the "territorial division" of the twelve Intendencias and the three peripheral Provincias (Brand 1959). Humboldt also concerned himself with the open question of the border of the United States of America with the frontier moving vehemently west and southwest.

Numerous comparisons help the reader with 
the classification of Mexico's importance in the Spanish colonial empire and also globally. New Spain earned more than two thirds of the revenue of the Spanish colonies in America and Asia, and it also contributed about $15 \%$ of the total revenue of the Spanish government. Thus Mexico yielded twice as much for Spain as British-East India, with a population five times larger than the Mexican population, for Great Britain. Hence Humboldt's analysis, which contains government revenues, was not only important for the Spanish King but also for the evaluation of the global economy at that time. The handling of military defense in this "Essai" shows that the arrival of more troops in Spanish America reflects the increasing distrust of the government of the mother country toward interior and exterior dangers in the final phase of colonialism. Humboldt was later also criticized in Mexico as he left results of his research including maps and information on the military to the government of the USA during his 1804 visit.

Alexander von Humboldt has " in all frankness shown the unbearable condition of the late colonial mercantile system" (Troll 1959a), submitted numerous suggestions for improvement in all domains, and he has emphasized that the good of the white population involves the good of the Indians, who must share in progress.

The different economic and social conditions in prospering Mexico in contrast with the economically backward Andean regions have led Humboldt to comparative regional studies (Brand 1959); he took important natural as well as socio-economic and fiscal criteria into consideration (Beck 1966). The associated atlas (Humboldt 1811b; reprint 1969; reproduction of a few pages in the study edition Beck 1987/1997 - vol. IV, 1991, supplement) is a rich source for the explanation of basic problems in the form of maps, profiles, plans, graphics, etc. With it Humboldt created the first thematic atlas of a non-European continent (Beck 2000). The discussion of possible canal connections between the Atlantic and Pacific oceans was especially exciting (tables 3,17 ). Humboldt, rightly called the intellec- tual father of the Panama Canal by Frankel (1959), had pointed to the channel connection in the third edition of his "Ansichten der Natur" (1849) which became ever more urgent after the independence of Latin-American states and the fast development of the west coast of the USA.

Humboldt (1825) has devoted slavery a profound analysis in his work on Cuba (vol. III of the "Relation Historique") which he considered "the greatest of all evils," a "political crime,' inhumane, inefficient, and unnecessary. However, he concluded from a humanitarian perspective and also quite pragmatically that better treatment of the slaves would be profitable due to their decreased mortality. In the Spanish-American sphere of influence slave labor on plantations was generally not as important as in the southeast of the USA, on the British Antilles and also in Brazil (Pfeifer 1959a). However Humboldt attached great importance to this problem, also for Cuba's political future. $\mathrm{He}$ supported the colonial population's pursuit of liberty, and among these, Haiti was the first to free itself from European colonial rule. He criticized the corruption in the public administration in spite of all the privileges he enjoyed, e.g. travel permit and official support on site.

Humboldt experienced Cuba at the time when sugarcane-plantation economy expanded there due to Haiti's independence. While there were only 32,000 slaves working in Cuba in 1763, their number multiplied between 1790 and 1820, and in 1823 there were 260,000 slaves. Sugar exports rose by $600 \%$ between 1770 and 1823 . Humboldt made very interesting comparisons between the islands of the Antilles, where about 5 million African slaves had been brought between 1670 and 1825 , and the colonial rule of their mother countries. $55 \%$ of the then 1.15 million slaves of this region lived on the British Antilles, responsible for 58\% of the sugar exports. $25 \%$ of the slaves worked on Cuba (22\% of the sugar exports). The total of slaves on the Antilles, also called "sugar colonies," was almost three times higher than the labor force on the plantations. There were 3.3 million slaves in the New World, and 
two million of these in the Portuguese colony Brazil alone, which had lost its sugar export monopoly a long time ago. In 1823 it exported only $27 \%$ - the Caribbean region $62 \%$ - of the total volume of the New World. While in Cuba slaves represented 36\% of the population, on the British Antilles $81 \%$ of the population were slaves (cf. also Pfeifer 1959a,b; see Fig. 2). Humboldt estimated the Spanish legislation in relation to the British and French legislation more advantageous for the emancipation of slaves.

In 1856 Humboldt publicly opposed an unauthorized translation of his "Essai" in the USA which intentionally lacked the chapter on slavery. In the American election campaign - and a population divided in regard to slavery - this debate was " ammunition" for the opposing parties just before the War of Secession (Beck 1992). The "Essais" on Cuba - while with Goethe he talked of it as "my black book" - and also on Mexico are those publications in which Humboldt defended human rights so strongly that in independent Latin America he has remained unforgotten till this day.

Moreover, the essay on Cuba features a very meticulous compilation and substantiated interpretation of the population statistics, which was still updated in a supplement until 1829. Toward the beginning of the $19^{\text {th }}$ century La Habana was about the same size as New York and was the crossover point of the trade routes between the Old and the New World. It was also the leading trans-shipment center of Spanish America. Together with New York, Philadelphia, Mexico-City, Rio de Janeiro, and Salvador it belonged to the six metropolises of the New World, which, at the time of Humboldt's voyage, had already more than 100,000 inhabitants. MexicoCity was the largest city of the New World, and in 1820170,000 people lived there.

To name all of the numerous conceptual innovations which appear in Humboldt's works would go far beyond the scope of this article: isotherms, exogenous, endogenous, population density, and many others. His discoveries concerning the vertical circulation of seawater are responsible for the name "Humboldt-current" for the cold ocean cur- rent along the coastlines of Chile and Peru. In a letter to $\mathrm{H}$. Berghaus Humboldt modestly opposed the use of his name for the current, as his merit was not to discover it but only to measure its temperature and velocity (Schmieder 1964).

\section{THE RECEPTION OF HUMBOLDT'S EXPEDITION ACCOUNTS AND RESULTS OF HIS RESEARCH IN EUROPE}

Even before he set out on his great voyage Humboldt had already been a famous explorer. Already in 1794 he had met with Goethe and - without any positive resonance - with Schiller. In Paris he had an intensive exchange of ideas with the most important natural scientists of his time - e.g. Cuvier, Laplace, Lagrange, Berthollet, Saint-Hilaire, Bougainville, Lavoisier, Gay-Lussac, Fourcroy. Circumnavigations of the globe and important scientific expeditions were great sensations at the turn from the $18^{\text {th }}$ to the $19^{\text {th }}$ century (Pfeifer 1959a). The educated bourgeoisie devoured the accounts of such journeys in the same manner as the nobles and the political elite did. Humboldt's ability for narration which is both intriguing and also compressed as regards content, his joy in discussions and his comprehensive knowledge, which he managed to make good use of in regionally or thematically comparative approaches, made him a "star" at the Paris salon and also at the academy there. After Napoleon, who ignored the explorer Humboldt and saw the Prussian noble with distrust, Alexander von Humboldt had become the best-known man in Europe (Troll 1959a). The extensive collection Humboldt and Bonpland brought home from their journeys with great organization skill contributed to that. For security reasons and due to the precarious transportation conditions they had compiled several sets of the same collections and left them in different places (e.g. Paris, Berlin, Madrid). Scholars and illustrators in Paris began to join in working with the scientific material.

Overwhelmed by the comprehensive depth and width of Humboldt's scientific findings, the famous chemist Berthollet said in Paris: "Cet homme 


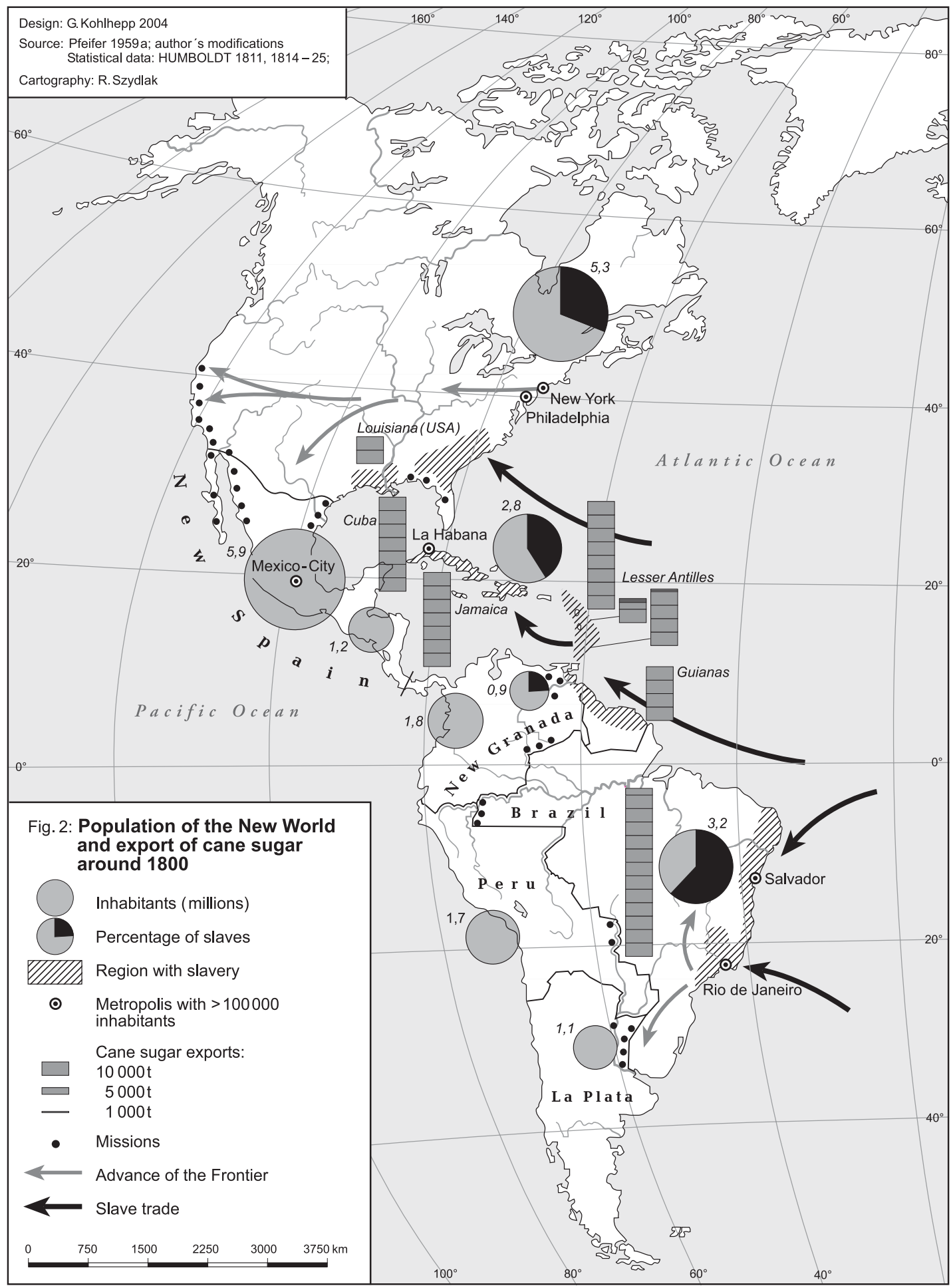

Fig. 2 
réunit toute une académie en lui." The art of substantiated and also exciting reporting quickly made Humboldt a famous man. "Only that natural scientist is admirable who knows every time how to describe and present the most foreign and the strangest with its locality, with its entire neighborhood in its very own element. How much I would like to hear Humboldt tell only once." (J.W. von Goethe: Die Wahlverwandtschaften 1808/1809; qu. in: Beck 1959).

Goethe was downright fascinated: "What kind of a man he is! I have known him so long, and yet he surprises me anew. One can say there is not one of his kind in knowledge and cognition. And a manysidedness I have never encountered before! Wherever one points, he is at home everywhere and overwhelms us with intellectual treasures" (J.W. von Goethe, in: J.P. Eckermann, December 1826. Gespräche mit Goethe; qu. in: Beck 1959). When Goethe received the work "Ideas for a geography of plants and a natural painting of the tropics" (1807) also dedicated to him, the "natural painting"'-table was missing. Yet thanks to Humboldt's detailed descriptions he himself designed an ideal profile of the altitudinal proportions of the Old and the New World with a couple of vegetation zones in an comparative and also opposite view (Goethe, in: Allgemeine Geographische Ephemeriden 41, vol. 1813: 3-8 with table; cf. Beck and Hein 1989 and Beck 1989).

Although Humboldt had been appointed member of the Prussian academy of sciences and was thus entitled to a pension after his return from the New World, he spent almost all his time from 1808 until 1827 in Paris where he concerned himself with the composing of the results of his research, which was published in French. This shows the scientific significance of the French metropolis. Yet not only the scientists and the scientific institutes attracted Humboldt, but the high technical quality of the print shops and the publishers' greater willingness to market magnificently equipped, comprehensive works. However, high costs, uneconomic proceedings and faulty planning in the editing process of the biggest private account of a journey in his- tory (Beck 1987/1997) exhausted Humboldt's capital (Löwenberg 1872) causing lifelong debts. Yet the Kosmos-work (1845/1862) then turned out to be "the first scientific bestseller in the first half of the $19^{\text {th }}$ century" (Beck 1993), and people downright fought over the quick purchase of the work.

Alexander von Humboldt's publications, beginning with the account of his journey, have had great influence on German natural scientists. Zoologists, botanists, geologists, geographers, and ethnologists found their research objectives in South America. The composition and publication of the research of e.g. J.B. von Spix and C.F.Ph. von Martius still took many decades after the publication of the account of their journey (Spix and Martius 1823/1831).

\section{CONCLUSION}

Alexander von Humboldt's scientific reputation all over the world is above all associated with his journey to the tropics of the New World. Many different disciplines consider Humboldt one of their scientific forerunners. Could anything better ever happen to a scientist? In his universal approach Humboldt, who did not consider himself a universal genius (Beck 1986), has given essential impulses in astronomy, mathematics, physics, meteorology, climatology, oceanography, chemistry, pharmacy, botany, zoology, geology, mineralogy, volcanology, archaeology, history, sociology, agronomy, ethnology, and medicine. Yet it is in the field of geography that his work has come to have the greatest significance, more so than in any of these fields, which were first subdivided into special subjects especially in the natural sciences - in the course of the 19th century. Experts in the individual fields mentioned above rightly point to the great impact his studies have had on Latin America (cf. Greive 1993). In today's computer era it deserves to be stressed that, 200 years ago, Humboldt himself created a comprehensive network designed to make interdisciplinary and international communication possible. He mailed about 35,000 handwritten let- 
ters, received about 100,000, discussed his knowledge, enlarged it, and he also substantiated it.

As a physical geographer, founder of plant and climatic geography, as an author of problemoriented regional studies with a strong involvement in conditions relevant to human geography and geopolitics, as a cartographer, and with the didactically skilful graphic presentation of profiles he set the standards for the modern development of geography as a science. According to Hettner (1927) " a new age for geography has dawned with the year 1799 . It is the year when Alexander von Humboldt set out on his great American journey; we must ascribe the greatest advances in geography to this journey: the foundation of several branches of general geography as well as the foundation of scientific regional geography." "It is Alexander von Humboldt's everlasting merit $[\ldots]$ that on his great South- and Central-American journey he [...] recorded and also presented the total character of countries and their inhabitants in a splendid way' (p. 77). Carl Ritter considered Humboldt the scientific discoverer of America. Beck (1996) praised him as the "greatest geographer of modern times."

In 1827 Alexander von Humboldt returned from Paris to Berlin - following the wish of the Prussian King Friedrich Wilhelm III, who wanted to help Berlin to achieve a certain amount of scientific acclaim - mainly due to private financial problems. Although he had already rejected many high positions, he had many obligations as appointed chamberlain and advisor at the Prussian court in Berlin. Thus when the "Gesellschaft für Erdkunde" was founded in Berlin in 1828 he could not assume the office of president himself. Carl Ritter became president of the society. He had held the first chair of geography at the Berlin University since 1820, and he remained president of the society for 21 years. Humboldt, who became honorary member of the "Gesellschaft für Erdkunde" and made many suggestions for its programs and the journal (GFE 2003), stayed in close contact with Ritter for three decades. Ritter and Humboldt laid the foundation for the development of geography in the $19^{\text {th }}$ century
(Pfeifer 1960). It was the "classical" phase of German geography, which played a key role during this period. The "Gesellschaft für Erdkunde zu Berlin" honored Alexander von Humboldt with festschrifts in 1899 (GFE 1899) and 1959 (Schultze 1959).

The personality Alexander von Humboldt had many facets. He combined concentration on his scientific activities and enthusiasm with open-mindedness and sociableness. Thanks to his noble ancestry and his social finesse he had the best relations with important politicians, created a network of work contacts with leading scientists but also with prominent personalities of the intellectual and cultural life. On his journeys he was unprejudiced, he skillfully dealt with members of lower social classes, and he respected his Indian helpers. He compensated for craving for recognition as an ingenious orator, who was always in the center in academic and scientific circles, and the ambitious realization of his projects with helpfulness to younger colleagues and unselfishness.

Despite his social position at the Prussian court and his privileges granted by the Spanish monarch during his expeditions he presented himself as a liberal and extremely critical scientist, especially when reporting about the degrading slave economy in the feudal system of the latifundia of the New World. Although his health was actually weak he stood the exhausting journeys in the tropical rainforests or in the Andean highlands all the way to the tierra helada with a great deal of persistence and energy, except for a troublesome and severe rheumatism condition (Plewe 1970). Besides many honors Alexander von Humboldt, who was considered a spy at the beginning of his journey to the tropics and was forbidden to enter the Portuguese colony Brazil, received a medal of honor from the imperial Brazilian government in 1855 . He acted as umpire in a border dispute between Brazil and Venezuela and decided in favor of Brazil (Pfeifer 1970).

Alexander von Humboldt as an explorer with an ingenious capacity of observation and never ending scientific curiosity has contributed a great deal 
to the development of the image of the "New World" in Europe. In particular he has managed to familiarize European science and later also a larger audience with huge parts of the Central and South American tropics. He did much for the Europeans' understanding of Latin America and contributed to the development of a Latin-American identity. In 1823 Simón Bolívar emphasized that Humboldt had done more for South America than all conquerors (Heiman 1959).

It would be justified to call Alexander von Humboldt with his holistic understanding of nature and scientific plan (Meyer-Abich 1993) the founder of a problem-oriented research on the tropics, which exceeded the mere description of "exotic" details and also put forth the first approaches of a systematics of tropical ecology. Today's research on the tropics and Latin America-research in Germany are judged in light of this tradition.

Humboldt failed to achieve one thing: he could never realize his dream to retire in Mexico and open a large central institute of sciences. Toward the beginning of the $19^{\text {th }}$ century no city of the New World - not even in the USA - had scientific institutions as important as Mexico-City (Pfeifer 1959a). While his travel companion Bonpland (1773/1858) returned to South America (Paraguay, Argentina), whose stay had a very tragic character due to his capture (1821/1831) by the Paraguayan dictator Francia, Alexander von Humboldt did not live to see the New World again; he died in 1859. It is in Latin America where Humboldt has remained unforgotten. This is not only true for the sciences where his contribution was and still is very substantially analyzed (among others Unam 1962, Martínez and Hampe 1999, Greiff 1999), and till this day his contribution is admired as the first great transfer of research results in favor of the young independent Latin America. The naming of numerous topographic points after him and the lively interest in this personality attest to his influence. This is reflected in monuments, places named after him, roads, institutes, scientific societies, museums, schools, etc, and also in public honors on memorial days in ad- miration for the unprejudiced German scholar and his innovating ideas. In Mexico he was posthumously awarded the title "Benemérito de la Patria," in Venezuela "Servidor Eminente de Venezuela.' In 1959 the new Cuban leadership under Fidel Castro insisted upon celebrating the $100^{\text {th }}$ anniversary of Humboldt's death four months after their coming into power.

In face of the fact that in Latin America Alexander von Humboldt is commemorated more than in Germany - however, see among other things the extraordinarily deserving publication and annotation of the study edition by Beck 1987/1997, the comprehensive research of the Berlin-Brandenburg Academy of Sciences (BBAW) since 1983, Greive 1993, Inter Nationes 1999, Diálogo Científico 8, 2, 1999 - it is especially agreeable that a "Wilhelm and Alexander von Humboldt-chair" was established in Mexico in October 1998 funded by the DAAD. There students and scientists from Mexico can concern themselves with Germany-studies.

In the sense of Humboldt's humanistic worldview, who overcame the eurocentric way of thinking and was "at home"' in the Old as well as in the New World, this is a contribution to the advancement and the continuation of the dialogue and the intensification of the scientific relations between Latin America and Germany. In remembrance of the great explorer it is the central aim of the German "Alexander von Humboldt-Foundation' to keep these contacts alive all over the world.

\section{RESUMO}

A expedição científica de Alexander von Humboldt de 1799 a 1804 pela região equinocial do novo mundo foi realizada através dos países Venezuela, Cuba, Colômbia, Equador, Peru e México. Esta viagem, destinada à obtenção de novos conhecimentos aprofundados sobre o "novo mundo" para a Europa, foi financiada com meios particulares e tinha exclusivamente objetivos científicos e não a exploração de recursos naturais. Paralelamente aos resultados de pesquisa, fundamentados em novos métodos de medida e da elaboração quantitativa de fundamentos 
das ciências naturais, a viagem proporcionou relatórios geográficos integrando fatos sociais, sócio-econômicos, políticos e da geografia econômica, tendo como base a pesquisa empírica de campo.

A expedição foi realizada pouco antes da mudança política radical na América Latina. Humboldt ainda presenciou a economia mundial, colonial e feudal, baseada na escravidão. Apesar de pertencer à aristocracia, von Humboldt criticou de forma veemente essa estrutura econômica e suas condições sociais insuportáveis. Por este fato e pelos resultados científicos obtidos quando da expedição aos trópicos e pelos impulsos inovativos dados à geografia e a muitas outras disciplinas científicas como erudito universal ele é admirado até os dias de hoje na América Latina e na Europa. Alexander von Humboldt marcou decisivamente o mundo científico na primeira parte do século XIX.

Palavras-chave: geografia histórica, estudos regionais, América Latina, colônias espanholas, Alexander von Humboldt.

\section{REFERENCES}

BBAW (Berlin-Brandenburgische AKademie DER Wissenschaften) (Ed.). Beiträge zur Alexandervon-Humboldt-Forschung. Vol. 1, 1983 - Vol. 22, 1997. Berlin.

BBAW. (Ed.). Berliner Manuskripte zur Alexander-vonHumboldt-Forschung. Vol. 1, 1990 - Vol. 25, 2002. Berlin.

BBAW AND INSTITUT FÜR ROMANISTIK, UNIVERSITÄT PoTsDAm (Eds.). Internationale Zeitschrift für Humboldt-Studien (electronic periodical; Internet: http:/ www.hin.online.de).

Beck H. 1959 (Ed.). Gespräche Alexander von Humboldts. Berlin, 492 p.

BECK H. 1959/1961. Alexander von Humboldt. Vol. I: Von der Bildungsreise zur Forschungsreise 17691804; vol II: Vom Reisewerk zum “Kosmos”' 18041859. Wiesbaden (Spanish translation: México 1971).

BecK H. 1966. Alexander von Humboldt und Mexico. Beiträge zu einem geographischen Erlebnis. Bad Godesberg (Spanish translation: México 1971).

BECK H. 1986. Alexander von Humboldt als größter Geograph der Neuzeit. In: Kessler, H. (Ed.). Die
Dioskuren. Probleme in Leben und Werk der Brüder Humboldt. Mannheim, p. 126-182.

BeCK H. 1987-1997 (Ed.). Alexander von Humboldt. Studienausgabe. 7 vol. Darmstadt (Forschungsunternehmen der Humboldt-Gesellschaft, nr. 40).

Beck H. 2000. Alexander von Humboldt - Kartograph der Neuen Welt. Profil des neuesten Forschungsstandes. In: HABERlAND, D ET AL. (Eds.). Die Dioskuren II. Annäherungen an Leben und Werk der Brüder Humboldt. Mannheim, p. 45-68.

Beck H ANd Hein W-H. 1989. Humboldts Naturgemälde der Tropenländer und Goethes ideale Landschaft. Stuttgart, $63 \mathrm{p}$.

Beck H And Meyer-Abich A. 1971. Alexander von Humboldts großes amerikanisches Reisewerk. Eine bibliographische Einleitung. New York, Amsterdam.

Bitterling R. 1954. Alexander von Humboldts Amerikareise in zeitgenössischer Darstellung. Petermanns Geographische Mitteilungen 98: 161-171.

BRAND DD. 1959. Humboldts Essai Politique Sur Le Royaume De La Nouvelle Espagne. In: Schultze, JH. (Ed.). Alexander von Humboldt. Studien zu seiner universalen Geisteshaltung. Berlin, p. 123141.

Bruhns K. 1872 (Ed.). Alexander von Humboldt. Eine wissenschaftliche Biographie. 2 vol. Leipzig.

BuIsson I. 1980. Die Unabhängigkeitsbewegungen in Iberoamerika. In: Buisson, I AND SCHOTTElius, H. Die Unabhängigkeitsbewegungen in Lateinamerika 1788-1826. Handbuch der lateinamerikanischen Geschichte. Teilveröffentlichung. Stuttgart, p. 1118.

Ette O. (Ed.). 1991. Alexander von Humboldt. Reise in die Äquinoktialgegenden des Neuen Kontinents. 2 vol. Frankfurt am Main, Leipzig.

FAAK M. 1986 (Ed.). Alexander von Humboldt. Reise auf dem Río Magdalena, durch die Anden und Mexico. Part I: Text. Aus seinen Reisetagebüchern zusammengestellt und erläutert durch M. Faak. Beiträge zur Alexander-von-Humboldt-Forschung, vol. 8. Berlin.

Fiedler H AND Leitner, U. 2000 Alexander von Humboldts Schriften. Bibliographie der selbständig erschienenen Werke. Beiträge zur A.v. HumboldtForschung 20. Berlin. 
Frankel WK. 1959. Alexander von Humboldt und der Panamakanal. In: Schultze, JH. (Ed.). Alexander von Humboldt. Studien zu seiner universalen Geisteshaltung. Berlin, p. 235-242.

GFE (GESELlschAFT FÜR ERDKUNDE ZU BERLIN) (Ed.). 1899. Wissenschaftliche Beiträge zum Gedächtnis der hundertjährigen Wiederkehr des Antritts von Alexander von Humboldt's Reise nach Amerika am 5. Juni 1799. - On the ocasion of the $7^{\text {th }}$ International Geographical Congress. Berlin.

GFE (GESELLSCHAFT FÜR ERDKUNDE ZU BERLIN) (Ed.). 2003. 175 Jahre Gesellschaft für Erdkunde zu Berlin. - DIE ERDE, Sonderheft 1. Berlin.

GREIFF JA DE. 1999. Encuentro de Humboldt con la ciencia en la España americana: diálogos inesperados. Diálogo Científico, Tübingen 8: 25-35.

Greive W. (Ed.). 1993. Alexander von Humboldt. Die andere Entdeckung Amerikas. Loccumer Protokolle 10/1992. Loccum.

Hard G. 1969. "Kosmos" und "Landschaft" - Kosmologische und landschaftsphysiognomische Denkmotive bei Alexander von Humboldt und in der geographischen Humboldt-Auslegung des 20. Jahrhunderts. In: Pfeiffer, H. (Ed.). Alexander von Humboldt. Werk und Weltgeltung. München, p. 133-177.

HARD G. 1970. Der "Totalcharakter der Landschaft". Re-Interpretation einiger Textstellen bei Alexander von Humboldt. In: Wilhelmy, H, EngelmanN, G and Hard, G. Alexander von Humboldt. Eigene und neue Wertungen der Reisen, Arbeit und Gedankenwelt. Erdkundliches Wissen 23 (= Geographische Zeitschrift, Beihefte): Wiesbaden, p. 49-73.

Heiman H. 1959. Humboldt und Bolívar. Begegnung zweier Welten in zwei Männern. In: Schultze, JH. (Ed.). Alexander von Humboldt. Studien zu seiner universalen Geisteshaltung. Berlin, p. 215-234.

Hettner A. 1927. Die Geographie, ihre Geschichte, ihr Wesen und ihre Methoden. Breslau, 463 p.

Humboldt A von. 1805/1807. Essai sur la géographie des plantes, accompagné d'un tableau physique des régions équinoxiales. Paris.

Humboldt A von. 1807. Ideen zu einer Geographie der Pflanzen nebst einem Naturgemälde der Tropenländer. Tübingen and Paris, 182p. (revised edition of the 'Essai').
Humboldt A von. 1808a. Géographie des plantes équinoxiales. Tableau physique des Andes et pays voisins. Paris.

Humboldt A von. 1808b. Ansichten der Natur, mit wissenschaftlichen Erläuterungen. Tübingen. ( $2^{\text {nd }}$ revised edition: Stuttgart and Tübingen 1826, 2 vol.; $3^{\text {rd }}$ edition: Stuttgart and Tübingen 1849.)

Humboldt A von. 1811a. Essai politique sur le royaume de la Nouvelle-Espagne. 2 vol. [with Atlas]. Paris.

Humboldt A von. 1811b. Atlas géographique et physique du royaume de la Nouvelle-Espagne. Paris, 4p. (Reprint: Mexico-Atlas. Introduction by H. Beck and W. Bonacker. In: BECK, H. (Ed.). 1969. Quellen und Forschungen zur Geschichte der Geographie und der Reisen 6. Stuttgart.)

Humboldt A von. 1814/1825. Relation historique du voyage aux régions équinoxiales du Nouveau Continent, fait en 1799, 1800, 1801, 1802, 1803 et 1804, par A. de Humboldt e A. Bonpland. Rédigé par Alexandre de Humboldt. Paris, vol. I 1814, vol. II 1819, vol. III 1825 (Reprint: With introduction and index by H Beck, In: Beck H. (Ed.). 1970. Quellen und Forschungen zur Geschichte der Geographie und der Reisen 8. Stuttgart, 3 vol.)

Humboldt A von. 1814a. Atlas pittoresque, 2 vol. (vol. I Text, vol. II Atlas). Paris.

Humboldt A von. 1814b. Atlas géographique et physique des régions équinoxiales du Nouveau Continent, fondé sur des observations astronomiques, des messures trigonométriques et des nivellements barométriques par A. de Humboldt. Paris, 11 p.

Humboldt A von. 1845/1862. Kosmos. Entwurf einer physischen Weltbeschreibung. - Stuttgart and Tübingen, 5 vol.

Humboldt A von. 1987. Ansichten der Natur. - In: BECK, H. (Ed.). Alexander von Humboldt. Studienausgabe, vol. V. - Darmstadt (H Beck: commentary: 361-376)

Humboldt A von. 1989a. Schriften zur Geographie der Pflanzen. In: BECK, H. (Ed.). Alexander von Humboldt. Studienausgabe, vol. I. Darmstadt (H Beck: commentary: 287-328).

Humboldt A von. 1989b. Schriften zur physikalischen Geographie. In: BECK, H. (Ed.). Alexander von Humboldt. Studienausgabe, vol. VI. Darmstadt (H Beck: commentary: 185-215). 
Humboldt A von. 1991. Mexico-Werk. Politische Ideen zu México. Mexicanische Landeskunde. In: Beck, H. (Ed.). Alexander von Humboldt. Studienausgabe, vol. IV. Darmstadt (H Beck: commentary: 527-578), 17 plates.

Humboldt A von. 1992. Cuba-Werk. In: Beck, H. (Ed.). Alexander von Humboldt. Studienausgabe, vol. III. Darmstadt (H Beck: commentary: 229264), 1 map.

Humboldt A von. 1993. Kosmos. Entwurf einer physischen Weltbeschreibung. In: BECK, H. (Ed.): Alexander von Humboldt. Studienausgabe, vol. VII, 2 parts. Darmstadt (H Beck: commentary, part 2: 341-425), 8 plates.

Humboldt A von. 1997. Die Forschungsreise in den Tropen Amerikas. In: BECK, H. (Ed.). Alexander von Humboldt. Studienausgabe, vol. II, 3 parts. Darmstadt (H Beck: commentary, part 3: 371-489).

InTER NATIONES (Ed.). 1999. Alexander von Humboldt. Bicentenário da viagem americana 1799-1804. Humboldt, ano 41, no. 78. Bonn; and: Bicentenario del viaje americano. 1799-1804. Humboldt, año 41, no. 126. Bonn.

Kessler H. 1986 (Ed.). Die Dioskuren. Probleme in Leben und Werk der Brüder Humboldt. Abhandlungen der Humboldt-Gesellschaft für Wissenschaft, Kunst und Bildung, vol. 9. Mannheim.

Kohlhepp G. 1999. Alexander von Humboldt en los tropicos del Nuevo Mundo. Reflexiones sobre el bicentenario del inicio de su "Viaje a las regiones equinocciales', en 1799. Diálogo Científico, Tübingen 8: 9-24.

KRÄTz O. 1997. Alexander von Humboldt. Wissenschaftler - Weltbürger - Revolutionär. München, 214 p.

Lauer W. 1975. Vom Wesen der Tropen. Klimaökologische Studien zum Inhalt und zur Abgrenzung eines irdischen Landschaftsgürtels. Mainz, Wiesbaden.

LöwenberG J. 1872. Alexander von Humboldt, Bibliographische Übersicht seiner Werke, Schriften und zerstreuten Abhandlungen (Unchanged reprint, Stuttgart 1960. In: BruHNS, K. (Ed.). Alexander von Humboldt. Eine wissenschaftliche Bibliographie. vol. 1. Leipzig.

Martínez T And HAMPe. 1999. Treinta años de bibliografía humboldtiana en lengua espanhola (19691999). Diálogo Científico, Tübingen 8: 36-56.
Meyer-Abich KM. 1993. Naturkunde des Geistes Alexander von Humboldts Naturverständnis und sein ganzheitlicher Wissenschaftsentwurf. In: GREIVE, W. (Ed.). Alexander von Humboldt. Die andere Entdeckung Amerikas. Loccumer Protokolle 10/1992: 52-76. Loccum.

Otremba E. 1959. Die Llanos des Orinoco und des Apure in der Landschafts- und Reisebeschreibung Alexander von Humboldts. In: Schultze, JH. (Ed.). Alexander von Humboldt. Studien zu seiner universalen Geisteshaltung: Berlin, p. 69-89.

Petermann A. 1869. Übersichtskarte von Alexander von Humboldt's Reisen 1798-1829. Mitteilungen aus Justus Perthes' Geographischer Anstalt 15: 292 294 and plate 16 . Gotha.

Pfeifer G. 1959a. Die Neue Welt in der Perspektive Alexander von Humboldts. Erdkunde. Bonn 13: 395-411.

Pfeifer G. 1959b. Alexander von Humboldt (18591959). Beiträge zur Würdigung seiner Persönlichkeit anlässlich der Gedenkfeiern in Süd- und Mittelamerika im Jahre 1959. In: SitzungSBERICHTE Der Physikalisch-Medizinischen Sozietët ERLANGEN, Erlangen 80: 15-46.

Pfeifer G. 1960. Ritter, Humboldt und die moderne Geographie. In: Otremba, E et AL. (Eds.). Tagungsbericht und wiss. Abhandlungen, Deutscher Geographentag, Berlin. 1959: 69-83. Wiesbaden.

PfeIfER G. 1970. Drei Nächte in San Carlos. A. von Humboldt an den Grenzen Brasiliens. Deutsch-Brasilianische Hefte. Bonn 9: 74-85, 162-169.

Pfeiffer H. 1969 (Ed.). Alexander von Humboldt. Werk und Weltgeltung. München, 505 p.

Plewe E. 1970. Alexander von Humboldt 1769-1969. Schriften der Gesellschaft der Freunde Mannheims und der ehemaligen Kurpfalz 10: 1-31. Mannheim (reprint) In: Plewe, E. Geographie in Vergangenheit und Gegenwart. Ausgewählte Beiträge zur Geschichte und Methode des Fachs (Eds. E. Meynen and U. Wardenga). Erdkundliches Wissen 1986. Stuttgart 85: 222-248).

SCHMieder O. 1964. Alexander von Humboldt. Persönlichkeit, wissenschaftliches Werk und Auswirkung auf die moderne Länderkunde. Geographische Zeitschrift. Wiesbaden 52: 81-95. 
SchultZE JH. 1959 (Ed.). Alexander von Humboldt. Studien zu seiner universalen Geisteshaltung. Festschrift aus Anlass der 100. Wiederkehr seines Todestages. Berlin, $277 \mathrm{p}$.

SPIX JB von AND Martius CFPh von. 1823-1831. Reise in Brasilien in den Jahren 1817-1820, 3 vol., 1 Tafelband. München (Reprint, ed. by K. Mägdefrau. In: BECK, H. (Ed.). Quellen und Forschungen zur Geschichte der Geographie und der Reisen 3; 3 vol. Stuttgart 1980).

Stevens-Middleton RL. 1956. La obra de Alexander von Humboldt en México. Fundamento de la geografía moderna. Instituto Panamericano de Geografía e Historia, Publicación No. 202. México, D.F.

Stevens RL. 1959. Alexander von Humboldt als wissenschaftlicher Reisender und als Naturbeobachter. In: Schultze, JH. (Ed.). Alexander von Humboldt. Studien zu seiner universalen Geisteshaltung: Berlin, p. 1-35.

Troll C. 1959a. Alexander von Humboldts wissenschaftliche Sendung. Festrede, gehalten am 19. Mai 1959 in Berlin aus Anlass der Alexander-von-Humboldt-Feier. In: Schultze, JH. (Ed.): Alexander von Humboldt. Studien zu seiner universalen Geisteshaltung. Berlin, p. 258-277.

Troll C. 1959b. Die tropischen Gebirge. Ihre dreidimensionale klimatische und pflanzengeographische Zonierung. Bonner Geographische Abhandlungen 25. Bonn, $93 \mathrm{p}$.

Troll C. 1969. Die Lebensformen der Pflanzen. Alexander von Humboldts Ideen in der ökologischen Sicht von heute. In: PfEIfFEr, H. (Ed.). Alexander von Humboldt. Werk und Weltgeltung. München, p. 197-246.
Universidad Nacional Autónoma de México (UNAM). 1962 (Ed.). Ensayos sobre Humboldt. México, D.F.

VARESCHI V. 1959. Geschichtslose Ufer. Auf den Spuren Humboldts am Orinoko. München.

Wilhelmy H. 1970. Gestalt eines Großen. Alexander von Humboldt in der Sicht seiner amerikanischen Reise. In: Wilhelmy H, EngelmanN G AND HaRD G. Alexander von Humboldt. Eigene und neue Wertungen der Reisen, Arbeit und Gedankenwelt. Erdkundliches Wissen (=Geographische Zeitschrift, Beihefte), Wiesbaden 23: 1-22.

WiLhelmy H. 1986. Humboldts südamerikanische Reise und ihre Bedeutung für die Geographie. In: KessLER H. (Ed.). Die Dioskuren. Probleme in Leben und Werk der Brüder Humboldt. Abhandlungen der Humboldt-Gesellschaft für Wissenschaft, Kunst und Bildung, vol. 9. Mannheim: 183-198. Also in: Gormsen E AND LenZ K. 1987 (Eds.). Lateinamerika im Brennpunkt. Aktuelle Forschungen deutscher Geographen. Ein Symposium der Gesellschaft für Erdkunde zu Berlin zum 125. Todestag Alexander von Humboldts. Berlin, p. 9-23.

ZEA L. 1993. Alejandro de Humboldt, autodescubrimento de America. In: Greive H. (Ed.). Alexander von Humboldt. Die andere Entdeckung Amerikas. Loccumer Protokolle 10/1992: 36-51. Loccum. 